\title{
Organizational Effectiveness: A Second-order Confirmatory Factor Analysis
}

\author{
Waiphot Kulachai ${ }^{1}$, S. Vuttivoradit ${ }^{2}$, A.P. Tedjakusuma ${ }^{3} \&$ P. Homyamyen ${ }^{4}$
}

\author{
${ }^{1}$ Suan Sunandha Rajabhat University, Bangkok, Thailand \\ ${ }^{2}$ Suan Sunandha Rajabhat University, Bangkok, Thailand \\ ${ }^{3}$ University of Surabaya, Surabaya, Indonesia \\ ${ }^{4}$ Rajamangala University of Technology Suvarnabhumi, Suphanburi, Thailand \\ *Corresponding author. Email: waiphot.ku@ssru.ac.th
}

\begin{abstract}
Organizational effectiveness has caught the attention of scholars for decades since it indicates the efficiency and achievement of an organization. However, measuring organizational effectiveness is quite difficult and controversial since there are various approaches to measure it. Recently, there are four popular approaches employed by researchers: goal-attainment, system, strategic constituencies, and competing-values. Some scholars recommend multiple approaches to measure organizational effectiveness. In this study, the organizational effectiveness measure (OEM) was developed based on a competing-values approach and Kareem (2019). The OEM then was tested whether measures of a construct are consistent with theories. After conducting second-order confirmatory factor analysis, the findings indicate two dimensions: resource optimization and stability that can measure organizational effectiveness well. However, to use and apply this measurement, the organization's context and environment should be considered. In addition, multiple approaches are recommended for private organizations.
\end{abstract}

Keywords: organizational effectiveness, resource optimization, stability.

\section{INTRODUCTION}

Organizational effectiveness is critical to the management of an organization since it measures how thoroughly and efficiently a company achieves its business goals. It is also an indication factor of the success of the organization's leader, who demonstrates the ability, potential, leadership, and responsibility in the administration (Jones 2002). Organizational effectiveness has no standard definition. Traditionally, this concept has been viewed as productivity. Sometimes, organizational effectiveness is called "organizational success or organizational worth" (Georgopoulos \& Tannenbaum 1957) or or- ganizational performance (Lee \& Choi 2003). Generally, it refers to goal-attainment or mobilization of human and other resources to achieve the organization's collective goals and purposes. This is consistent with the opinion of Fallon \& Brinkerhoff (1996), who define organizational effectiveness as "a company's long-term ability to achieve its strategic and operational goals consistently." Seashore \& Yuchtman (1991) define organizational effectiveness as the organization's ability to bring in limited and valuable resources from the environment to support and benefit an operation of the organization. Georgopoulos \& Tannenbaum (1957) reveal a broader definition of organi 
zational effectiveness as "the extent to which an organization as a social system, given certain resources and means, fulfills its objectives without incapacitating its means and resources and without placing undue strain upon its members." In this study, organizational effectiveness is defined as the extent to which an organization can achieve its goals.

Measuring organizational effectiveness is quite controversial. Eddy (1981) says that there should be three levels of measuring organizational effectiveness: individual, managerial, and organizational. Robbins (1990) proposes four approaches to measuring organizational effectiveness: goal-attainment, system, strategic-constituencies, and competing-values.

According to the goal-attainment approach, organizational effectiveness can be measured by the ability of the organization to achieve the organizational goals. This approach assumes that the organization must have real goals that can be seen and understood, the number of goals is not too high, and the organization members should agree on the goals. However, Cameron (1981) suggests that the organization will achieve its goals, but the organization may be ineffective if the goals are too low, displaced, or detrimental to the organization.

The system approach places importance on the ability of the organization to find inputs, convert inputs into output, survive in a changing environment, and have an interdependent relationship among different parts of the organization. The advantage of this approach is its emphasis on long-term goals of the organization, relationships among different parts of the organization, and other indicators to evaluate organizational effectiveness could be applied if the organization's goals are ambiguous. This approach also has some throwbacks since some variables, such as the organization's ability to adapt to a changing environment, are difficult to measure. This approach also makes scholars more interested in studying the means than the ends of an organization.
The strategic-constituencies approach believes that if an organization can know which group or any person is important to the organization and win the heart of that group or that person would avoid those individuals and groups from taking any action against the organization. Thus, to survive, the organization must be able to respond well to the needs of those individuals and interest groups. The limitation of this concept is difficulty identifying who or which group is more critical to the organization. In addition, finding accurate information about the needs of individuals and interest groups can be quite difficult.

According to the competing values approach, organizational effectiveness is measured based on who the assessors and what their values are. Individuals who make decisions on an organization's goals have different values. Managements, production managers, and others all have different ideas on the criteria for evaluating organizational effectiveness. This approach measures organizational effectiveness by considering the conflicting values of the people in the organization on three dimensions. The first dimension is flexibility or control of the organization. The second one is focusing on people or organizations. The third one is looking at the internal processes and the organization's methods and goals.

Mott (1972) measures organizational effectiveness in terms of productivity, adaptability, and efficiency. Sharma \& Samantara (1995) also apply this concept in their study. Gibson et al. (1982) describe five major indicators for measuring organizational effectiveness: production, efficiency, satisfaction, adaptiveness, and development. Gold et al. (2001) propose three dimensions of organizational effectiveness: innovation, coordination, and rapid commercialization of new products. Shoo (2016, as cited in Kareem 2019) argues that multi-approach should be applied in measuring organizational effectiveness. This idea has influenced the study conducted by Kareem (2019), who employs three approaches in his study: goal attainment, system, and competing-values. Based 
on these three approaches, he measures organizational effectiveness with four items for each approach, as illustrated in Table 1.

Table 1. Measurement of organizational effectiveness

\begin{tabular}{cl}
\hline Item & \multicolumn{1}{c}{ Statement } \\
GAal-attainment approach & $\begin{array}{l}\text { Our universitylinstitute ensures goal } \\
\text { achievement }\end{array}$ \\
GA2 & $\begin{array}{l}\text { Our universitylinstitute has an effective } \\
\text { strategic planning }\end{array}$ \\
GA3 & $\begin{array}{l}\text { Our universitylinstitute encourages the in- } \\
\text { novation }\end{array}$ \\
GA4 & $\begin{array}{l}\text { Our universitylinstitute makes efforts to } \\
\text { improve the quality }\end{array}$ \\
System resource approach \\
SRA1 $\begin{array}{l}\text { Our universitylinstitute has the ability to } \\
\text { acquire resource }\end{array}$ \\
SRA2 $\begin{array}{l}\text { Our universitylinstitute has good physical } \\
\text { infrastructures and equipment }\end{array}$ \\
SRA3 $\begin{array}{l}\text { Our universitylinstitute ensure the ac- } \\
\text { creditation }\end{array}$ \\
SRA4 $\begin{array}{l}\text { Our universitylinstitute encourages the } \\
\text { organizational health }\end{array}$ \\
Competing values approach \\
CVA1 $\begin{array}{l}\text { Our universitylinstitute makes efforts to } \\
\text { improve the productivity } \\
\text { Our universitylinstitute adapts to the } \\
\text { changing environment } \\
\text { Our universitylinstitute makes efforts to } \\
\text { the optimization of resources } \\
\text { Our universitylinstitute makes efforts to } \\
\text { the stability }\end{array}$ \\
CVA3
\end{tabular}

Source: Kareem (2019)

In this study, the authors apply the competing values approach to measure organizational effectiveness, replicating Kareem's (2019) study. In Kareem's study, he measures organizational effectiveness in four aspects, productivity, ability to adapt to the changing business environment, optimizing resources, and stability and flexibility with a single item for each aspect. In this study, the authors adjusted the scale by adding four items for each dimension.

Hence, there are five items for each dimension, as illustrated in Table 2. Then, this organizational effectiveness measure (OEM) was tested whether measures of a construct are consistent with theories reviewed by the authors.
Table 2. Organizational effectiveness measure (OEM)

\begin{tabular}{|c|c|}
\hline Item & Statement \\
\hline \multicolumn{2}{|c|}{ Productivity } \\
\hline PRO1 & $\begin{array}{l}\text { Your organization is making efforts to } \\
\text { improve production efficiency }\end{array}$ \\
\hline $\mathrm{PRO} 2$ & $\begin{array}{l}\text { Your organization can produce products } \\
\text { and services on time }\end{array}$ \\
\hline PRO3 & $\begin{array}{l}\text { Internal and external customers are satis- } \\
\text { fied with the services of the organization }\end{array}$ \\
\hline PRO4 & $\begin{array}{l}\text { Your organization can produce products / } \\
\text { services to meet the needs of customers }\end{array}$ \\
\hline PRO5 & $\begin{array}{l}\text { The production of products/services of } \\
\text { your organization provides good results }\end{array}$ \\
\hline \multicolumn{2}{|c|}{ Adaptation } \\
\hline ADA1 & $\begin{array}{l}\text { Your organization can adapt to the envi- } \\
\text { ronment well }\end{array}$ \\
\hline ADA2 & $\begin{array}{l}\text { Your organization has adjusted the image } \\
\text { of the organization all the time }\end{array}$ \\
\hline ADA3 & $\begin{array}{l}\text { Your organization has to adjust according } \\
\text { to the needs of customers }\end{array}$ \\
\hline ADA4 & $\begin{array}{l}\text { Your organization has adapted to meet } \\
\text { technological changes }\end{array}$ \\
\hline ADA5 & $\begin{array}{l}\text { Your organization has adjusted marketing } \\
\text { strategies regularly }\end{array}$ \\
\hline \multicolumn{2}{|c|}{ Resource Optimization } \\
\hline $\mathrm{RO} 0$ & $\begin{array}{l}\text { Your organization endeavors to optimize } \\
\text { most of its resources (Excluded) }\end{array}$ \\
\hline RO1 & $\begin{array}{l}\text { Your organization focuses on the savings } \\
\text { by reducing costs }\end{array}$ \\
\hline $\mathrm{RO} 2$ & $\begin{array}{l}\text { Various departments within the organiza- } \\
\text { tion have integrated the use of resources }\end{array}$ \\
\hline $\mathrm{RO} 3$ & $\begin{array}{l}\text { Your organization attaches great im- } \\
\text { portance to the use of resources for the } \\
\text { greatest benefit }\end{array}$ \\
\hline RO4 & $\begin{array}{l}\text { Your organization can reduce unnecessary } \\
\text { expenses }\end{array}$ \\
\hline \multicolumn{2}{|c|}{ Stability } \\
\hline STA1 & $\begin{array}{l}\text { Your organization has made great efforts } \\
\text { to provide stability to the organization }\end{array}$ \\
\hline STA2 & $\begin{array}{l}\text { Your organization is stable and able to } \\
\text { compete with competitors }\end{array}$ \\
\hline STA3 & You feel stable while working here \\
\hline STA4 & $\begin{array}{l}\text { Your organization has the ability to de- } \\
\text { velop products and services to create } \\
\text { business security for the organization }\end{array}$ \\
\hline STA5 & $\begin{array}{l}\text { Executives have the potential and the abil- } \\
\text { ity to create business security for the or- } \\
\text { ganization }\end{array}$ \\
\hline
\end{tabular}

\section{RESEARCH METHODS}

\subsection{Participants}

The participants of this study were $380 \mathrm{em}-$ ployees of a private company in Bangkok. Most of them were female, accounting for 
51.58 percent. The majority was in the age group of 31-40 years old. Approximately 55.79 percent were single. More than 50 percent of them has bachelor's degree, about 35.53 percent have been working in the company for 11-15 years, and over 32.37 percent earn a monthly income of 20,00130,000 Baht.

\subsection{Measures}

Organizational effectiveness measure (OEM) is created based on the competingvalues approach and the study conducted by Kareem (2019). Organizational effectiveness is divided into four dimensions, namely productivity, adaptation, resource optimization, and stability.

Productivity refers to an organization's effort to improve its efficiency, produce products and services on time, satisfy both internal and external customers, provide products and services that meet customers' needs and obtain good production results. This dimension is measured by a five-point Likert scale survey question anchored by strongly agree and strongly disagree. The measurement shows alpha reliability of 0.954 . The sample items are "your organization is making efforts to improve production efficiency," "your organization can produce products and services on time," and "internal and external customers are satisfied with the services of the organization."

Adaptation is an ability of an organization to adapt to the environment, such as customers' needs, technological changes, and marketing competition. This dimension is measured by a five-point Likert scale survey question anchored by strongly agree and strongly disagree. The measurement shows alpha reliability of 0.950 . The sample items are "your organization can adapt to the environment well," "your organization has adjusted the image of the organization all the time," and "your organization has to adjust according to the needs of customers."

Resource optimization is associated with the organization's effort to optimize limited resources by reducing unnecessary costs and integrating the use of resources. Firstly, this dimension is measured by a five-point Likert scale survey question anchored by strongly agree and strongly disagree. However, one item was excluded, so the measurement shows alpha reliability of 0.853 . The sample items are "your organization focuses on the savings by reducing costs," "various departments within the organization have integrated the use of resources," and "your organization attaches great importance to the use of resources for the greatest benefit."

Stability is associated with an effort of the organization to provide stability and security for the organization so it can gain competitive advantages. This dimension is measured by a five-point Likert scale survey question, anchored by strongly agree and strongly disagree. The measurement shows alpha reliability of 0.894 . The sample items are "your organization has made great efforts to provide stability to the organization," "your organization is stable and able to compete with competitors," and "your organization has the ability to develop products and services to create business security for the organization."

\subsection{Data Analysis}

A second-order confirmatory factor analysis was employed to analyze the collected data. This technique is very important to test whether measures of a construct are consistent with theories. Chi-square goodnessof-fit statistic and degree of freedom, two absolute fit indices (GFI, RMSEA), one incremental fit index (CFI), and one parsimony fit index (AGFI) are examined to check whether the model fits with the empirical data. (Hair et al. 2010).

\section{RESULTS AND DISCUSSIONS}

The results reveal the model chi-square of 807.097 with 149 degrees of freedom. The $p$-value is significant. The values of GFI and RMSEA, the absolute fit index, are 0.820 and 0.108 in that order. These values indi- 
cate the model does not fit with the empirical data. The normed chi-square is 5.417 which is over 2.00, indicating unfit for the CFA model. According to the incremental fit indices, the CFI, an incremental fit index, has a value of 0.669 , which is below the suggested cut-off values. In addition, the AGFI, a parsimony fit index, has a value of 0.771 , which reflects an unfit model. All information of goodness-of-fit statistics is illustrated in Figure 1 and Table 3.

Table 3 The CFA Goodness-of-fit statistics

\begin{tabular}{lr}
\multicolumn{1}{c}{ Goodness-of-fit statistics } & \multicolumn{1}{c}{ Value } \\
\hline Chi-square & 807.097 \\
Degree of freedom & 149 \\
$p$-value & .000 \\
Normed chi-square & 5.417 \\
GFI & .820 \\
RMSEA & .108 \\
CFI & .669 \\
AGFI & .771 \\
\hline
\end{tabular}

The authors also check model diagnostics since they may suggest a way for improving the model. The authors allow the errors of estimation to covariance in accordance with the modification indices. The CFA model is then re-estimated. The overall model fit statistics of the analysis are illustrated in Figure 2 and Table 4.

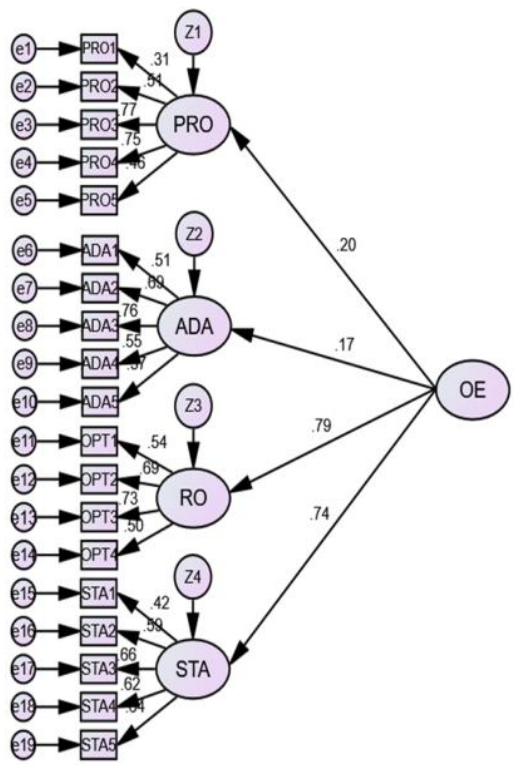

Chi-square $=807.097, \mathrm{df}=149$, Chi-square $/ \mathrm{df}=5.417, \mathrm{p}=.000, \mathrm{GFI}=.820$, $\mathrm{AGFI}=771, \mathrm{CFI}=669, \mathrm{RMSEA}=108, \mathrm{RMR}=091, \mathrm{NFI}=626$

Figure 1. CFA model of organizational effectiveness
The results reveal the model chi-square of 220.298 with 135 degrees of freedom. The $p$-value is insignificant. Hence, the chisquare goodness-of-fit statistic indicates that the observed covariance matrix matches the estimated covariance matrix within sampling variance.

Table 4 The CFA Goodness-of-fit statistics (Revised)

\begin{tabular}{|c|c|}
\hline Goodness-of-fit statistics & Value \\
\hline Chi-square & 220.298 \\
\hline Degree of freedom & 135 \\
\hline$p$-value & .000 \\
\hline Normed chi-square & 1.632 \\
\hline GFI & .943 \\
\hline RMSEA & .041 \\
\hline CFI & .957 \\
\hline AGFI & .919 \\
\hline
\end{tabular}

The values of GFI and RMSEA, the absolute fit index, are 0.943 and 0.041 in that order. This value indicates a good fit for the model. The normed chi-square is 1.632, which is below 2.00, indicating a good fit for the revised CFA model. According to the incremental fit indices, the CFI, an incremental fit index, has a value of 0.957 , which exceeds the suggested cut-off values. In addition, the AGFI, a parsimony fit index, has a value of 0.919 , which reflects an excellent model fit.

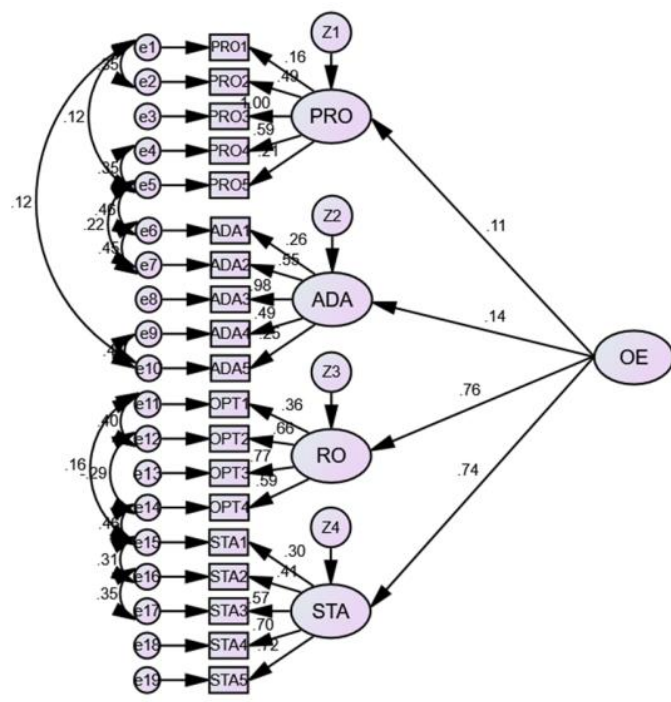

Chi-square $=220.298, \mathrm{df}=135, \mathrm{Chi}$-square $/ \mathrm{df}=1.632, \mathrm{p}=.000, \mathrm{GFI}=943$ $\mathrm{AGFI}=919, \mathrm{CFI}=957, \mathrm{RMSEA}=041, \mathrm{RMR}=068, \mathrm{NFI}=898$

Figure 2. CFA model of organizational effectiveness (Revised) 
Figure 2 also reveals that the four dimensions of organizational effectiveness have factor loading of 0.11 for productivity, 0.14 for adaptability, 0.76 for resource optimization, and 0.74 for stability. These indicate that only two dimensions (resource optimization and stability) contribute enormously to the organizational effectiveness construct. However, productivity and adaptability do not contribute strongly to this construct. The standardized factor loadings, an average convergent validity, and the construct validity are illustrated in Table 5.

According to Table 5, the lowest loading obtained is 0.16 productivity (PRO) to item "PRO1." Only five-factor loadings are greater than the 0.70 standard. The average variance extracted estimates, and the construct reliabilities are shown at the bottom of the Table. The AVE estimates range from $82.0 \%$ for adaptability to $86.8 \%$ for stability. All exceed the $50 \%$ rule of thumb. The construct reliabilities range from 0.945 for productivity construct to 0.968 for the stability construct. These exceed the 0.70 standard, which indicates adequate reliability.

Productivity (PRO) has five items with factor loadings range from $0.16-1.00$. The lowest factor loading obtained is 0.16 linking PRO to PRO1 "your organization is making efforts to improve production efficiency." The highest factor loading obtained is 1.00 linking PRO to PRO3 "internal and external customers are satisfied with the services of the organization." The results show an average variance extracted (AVE) of 0.824 suggesting adequate convergence. According to the CR of 0.945 , which greater than 0.70 , it suggests good reliability.

Adaptability (ADA) has five items with factor loadings range from $0.25-0.98$. The lowest factor loading obtained is 0.25 linking ADA to ADA5 "your organization has adjusted marketing strategies regularly." The highest factor loading obtained is 1.00 linking ADA to ADA3 "your organization has to adjust according to the needs of customers." The results show an average variance extracted (AVE) of 0.820 suggesting adequate convergence. According to the CR of 0.947 , which greater than 0.70 , it suggests good reliability.

Table 5. Standardized factor loadings, average variance extracted, and reliability estimates

\begin{tabular}{|c|c|c|c|c|}
\hline \multirow{2}{*}{$\begin{array}{l}\text { Dimension/Item } \\
\text { Productivity (PRO) }\end{array}$} & \multicolumn{4}{|c|}{$\begin{array}{c}\text { Standardized factor load- } \\
\text { ings }\end{array}$} \\
\hline & & & & \\
\hline PRO1 & .16 & & & \\
\hline PRO2 & .49 & & & \\
\hline PRO3 & 1.00 & & & \\
\hline PRO4 & .59 & & & \\
\hline PRO5 & .21 & & & \\
\hline \multicolumn{5}{|l|}{ Adaptability (ADA) } \\
\hline ADA1 & & .26 & & \\
\hline ADA2 & & .55 & & \\
\hline ADA3 & & .98 & & \\
\hline ADA4 & & .49 & & \\
\hline ADA5 & & .25 & & \\
\hline \multicolumn{5}{|c|}{ Resource optimization (RO) } \\
\hline RO1 & & & .36 & \\
\hline $\mathrm{RO} 2$ & & & .66 & \\
\hline RO3 & & & .77 & \\
\hline $\mathrm{RO} 4$ & & & .59 & \\
\hline \multicolumn{5}{|l|}{ Stability (STA) } \\
\hline STA1 & & & & .30 \\
\hline STA2 & & & & .41 \\
\hline STA3 & & & & .58 \\
\hline STA4 & & & & .70 \\
\hline STA5 & & & & .72 \\
\hline $\begin{array}{l}\text { Average variance ex- } \\
\text { tracted (AVE) }\end{array}$ & .824 & .820 & .858 & .868 \\
\hline $\begin{array}{ll}\text { Construct } & \text { reliability } \\
\text { (CR) } & \end{array}$ & .945 & .947 & .958 & .968 \\
\hline
\end{tabular}

Resource optimization (RO) has four items with the factor loading range from $0.36-0.77$. The lowest factor loading obtained is 0.36 , linking RO to RO1 "your organization focuses on the savings by reducing costs." The highest factor loading obtained is 0.77 linking $\mathrm{RO}$ to PRO3 "your organization attaches great importance to the use of resources for the greatest benefit." The results show an average variance extracted (AVE) of 0.858 suggesting adequate convergence. According to the CR of 0.958 , which greater than 0.70 , it suggests good reliability.

Stability (STA) has five items with the factor loading range from $0.30-0.72$. The lowest factor loading obtained is 0.30 linking STA to STA1 "your organization has made great efforts to provide stability to the organization." The highest factor loading obtained is 0.72 linking STA to STA5 "execu- 
tives have the potential and the ability to create business security for the organization." The results show an average variance extracted (AVE) of .868 suggesting adequate convergence. According to the CR of 0.968 , which greater than 0.70 , it suggests good reliability.

\section{CONCLUSION}

Organizational effectiveness is an indicator that reflects the ability of an organization to achieve its goals. However, there is a controversy on measuring organizational effectiveness. Hence, the authors try to develop an organizational effectiveness measure (OEM) based on the competing-values approach and the study conducted by Kareem (2019). In this study, four dimensions of organizational effectiveness were tested. The findings reveal that only two dimensions (resource optimization and stability) have factor loadings greater than the 0.70 standard. However, the factor loadings of productivity and adaptability are relatively low (0.11 and 0.14 , respectively). According to our analysis, the OEM demonstrates a very good validity, but some items should be excluded since their factor loadings do not meet the minimum standard. There are some limitations to this study. Firstly, this study applies a single approach (competing-values approach) to measure organizational effectiveness. Secondly, the authors apply organizational effectiveness based on Kareem's study, which focuses on the public university context, whereas the authors emphasize a private organization. Hence, measuring organizational effectiveness should be measured by multiple approaches. In addition, prior to using the OEM, the reliability and validity of the measurement should be examined according to similar organizational contexts and environments.

\section{REFERENCES}

Cameron, K. 1981. Domains of organizational effectiveness in colleges and universities. Academy of
Management Journal 24(1): 25-47. http://dx.doi.org/10.2307/255822

Eddy, W.B. 1981. Public organization behavior and development. Cambridge, MA: Winthrop.

Fallon, T. \& Brinkerhoff, R.O. 1996. Framework for organizational effectiveness. Proceedings. Paper presented at the American Society for Training and Development International Conference.

Georgopoulos, B.S. \& Tannenbaum, A.S. 1957. A Study of Organizational Effectiveness. American Sociological Review 22(5): 534-540.

Gibson, J.H., John, M.I. \& James, H.D. 1982. Organizations: Behavior structure and processes $\left(4^{\text {th }}\right.$ ed.). Austin, TX: Business Publications.

Gold, A.H., Malhotra, A. \& Segars, A.H. 2001. Knowledge management: an organizational capabilities perspective. Journal of Management Information Systems 18(1): 185-214.

Hair, J.F., Black, W.C., Babin, B.J. \& Anderson, R.E. 2010. Multivariate data analysis ( $7^{\text {th }}$ Ed.). NJ: Prentice Hall.

Jones, G.L. 2002. Organizational theory, design, and change. ( $3^{\text {rd }}$ ed.). Texas: Pearson Education.

Kareem, M.A. 2019. The impact of human resource development on organizational effectiveness: An empirical study. Management Dynamics in the Knowledge Economy 7(1): 29-50.

Lee, H. \& Choi, B. 2003. Knowledge management enablers, processes, and organizational performance: An integrative view and empirical examination. Journal of Management Information System 20(1): 179-228.

Mott, P.E. 1972. The characteristics of effective organizations. New York: Harper and Row.

Robbins, S.P. 1990. Organization Theory: Structure, design, and applications (3rd ed.). NJ: PrenticeHall.

Seashore, S.E. \& Yuchtman, E. 1991. A system in resource approach to organization effectiveness. Administrative Science Quarterly 32: 377-395.

Sharma, R.A. \& Samantara, R. 1995. Conflict management in an Indian firm. Indian Journal of Industrial Relations 30(4): 439-453. 